\title{
KOMUNIKASI RELIGIUS \\ (STUDI FENOMENOLOGI TENTANG KOMUNIKASI RELIGIUS KONVERSI AGAMA KRISTEN KE AGAMA ISLAM \\ DI GARUT KOTA)
}

\author{
Iis Zilfah Adnan', Zikri Fachrul Nurhadi', Achmad Wildan Kurniawan', \\ Kurniawan $^{4}$ \\ Universitas Garut
}

\begin{abstract}
This study aims to discover and explain the motives, experiences and meaning of conversion of religion from Christian Religion to Islam. The theory used is the theory of phenomenology that explains the structure of the conscious experience, as well as studying the form of experience from the point of view of the person who experienced it directly who has the openness and availability to be explored. This research method using qualitative approach through participant observation, depth interview, and literature study. The subject of research is the perpetrator who convert Christianity to Islam as the main informant who represented by purposive sampling technique which amounted to 7 people in Garut City. The result of the research shows that it produces several categorizations related to the motive of purpose (future), that is to get the happiness of the world and the hereafter, enlightenment, life balance, get ridho, magfiroh, togetherness and blessing, and motif because (past) marriage, perfect religion, acceptable common sense and one aqidah in couples. While the perpetrator's experience of happiness is born inward, gaining knowledge of the new teachings of religion, life becomes more valuable and affectionate. While the meaning contained for the actors is the change of life procedures, the procedures of worship, the movement of beliefs and guidelines in life.
\end{abstract}

Keywords:religious, conversion, religion, christianity, islam

\section{Pendahuluan}

Fenomena pindah Agama atau istilah lain konversi Agama selalu menjadi realitas yang mengejutkan, terutama di Indonesia. Tidak selalu terjadi pada individu yang melakukannya, bisa jadi terjadi pada keluarga, pihak lain yang bersangkutan, atau bahkan orang-orang disekitar lingkungan, serta dari tahun ke tahun trend pertumbuhan Mualaf terus mengalami peningkatan. Pada 2016, data dari Mualaf Center Indonesia setidaknya ada 2854 orang masuk Islam yang tersebar di seluruh Indonesia. Jumlah mualaf tertinggi terjadi pada tahun 2006. Meski tahun 2007 hingga 2009 sempat menurun. Namun pada tahun 2010, pertumbuhan jumlah mualaf kembali naik. Kemudian terus naik pada 2011, 2012, sampai sekarang naik terus angkanya. Paling tidak dalam lima tahun ke belakang sudah lebih dari 10 ribu orang masuk Islam. Kalau 
dihitung dari 2011, sudah lebih dari 10 ribu orang," ujar Ketua Mualaf Center Indonesia Steven Indra Wibowo belum lama ini. Steven juga mengungkapkan, penyumbang terbanyak jumlah mualaf justru dari daerah-daerah. ${ }^{1}$

Sementara khususnya Kabupaten Garut yang menjadi objek kajian ini memiliki masyarakat yang mempunyai Agama yang beragam terlebih banyaknya Etnis Tionghoa yang menetap di beberapa Kota di Kabupaten Garut menambah kuat adanya keberagaman Agama yang dianut oleh masyarakat, selain itu Kabupaten Garut merupakan daerah yang nyaman dan aman bagi para pendatang seperti halnya dari daerah Jawa, Sumatera ataupun daerah lainnya, tidak sedikit masyarakat pendatang tersebut memutuskan untuk menetap dan tinggal di kabupaten Garut. Menurut data dari Kementerian Agama Kabupaten Garut adanya peningkatan masyarakat yang melakukan perpindahan agama/keyakinan/konversi Agama baik dari agama Kristen ke agama Islam, dari agama Budha ke agama Islam maupun dari Agama lainnya di Garut kota khususnya pelaku konversi agama terbanyak dilakukan oleh pemeluk agama Kristen. Hal ini, dapat dilihat dari angka peningkatan pada tahun 2012 sampai dengan tahun 2016, data lengkap dapat dilihat pada tabel 1 sebagai berikut:

\section{Tabel 1}

\section{Data konversi Agama Kristen ke Agama Islam di Kabupaten Garut Tahun 2012-} 2016

\begin{tabular}{|l|l|l|l|l|}
\hline No & Tahun & Laki-laki & Perempuan & Jumlah \\
\hline 1 & 2012 & 4 & 1 & 5 \\
\hline 2 & 2013 & 5 & 3 & 8 \\
\hline 3 & 2014 & 6 & 2 & 8 \\
\hline 4 & 2015 & 2 & 2 & 4 \\
\hline 5 & 2016 & 7 & 4 & 11 \\
\hline \multicolumn{2}{|l}{ Total } & $\mathbf{2 4}$ & $\mathbf{1 2}$ & $\mathbf{3 6}$ \\
\hline
\end{tabular}

Sumber: Kementerian Agama Kabupaten Garut

Dari tabel 1 menunjukkan bahwa setiap tahunnya angka perpindahan 
agama/konversi agama di Kabupaten Garut khususnya di Garut kota terus meningkat. Gambaran pada tabel 1 peningkatan yang melakukan konversi agama berjumlah 36 orang dalam rentan waktu lima tahun terakhir yaitu tahun 2012 sampai dengan tahun 2016. Sekian banyak angka konversi Agama tersebut maka akan menghasilkan berbagai motif yang melatarbelakangi para pelaku konversi agama.

Konversi agama menurut etimologi konversi berasal dari kata latin "conversio" yang berarti tobat, pindah, berubah (agama). Selanjutnya kata tersebut dipakai dalam kata Inggris "conversion" yang mengandung pengertian: berubah dari suatu keadaan, atau dari suatu agama ke agama lain (change from one state, or from one religion, to another. Menurut Heirich (dalam Rakhmat, 2016: 331) mengatakan bahwa: Konversi Agama merupakan suatu tindakan di mana seseorang atau sekelompok orang masuk atau berpindah kesuatu system kepercayaan atau perilaku yang berlawanan dengan kepercayaan sebelumnya. Konversi agama sebagai suatu macam pertumbuhan atau perkembangan spiritual yang mengandung perubahan arah yang cukup berarti, dalam sikap terhadap ajaran dan tindak agama. Lebih jelas dan lebih tegas lagi, konversi agama menunjukan bahwa suatu perubahan emosi yang tiba-tiba kearah mendapat hidayah Allah SWT secara mendadak, telah terjadi, yang mungkin saja sangat mendalam atau dangkal, dan mungkin pula terjadi perubahan tersebut secara berangsurangsur (Daradjat, 2010: 50).

Berdasarkan pengamatan yang telah dilakukan oleh penulis pada tanggal $03 \mathrm{Mei}$ 2017, di beberapa kota di Kabupaten Garut diantaranya Garut Kota, Tarogong, dan Karangpawitan, data yang diperoleh yaitu jumlah terbanyak pemeluk agama Kristen di Kabupaten Garut berlokasi di Garut Kota sekitar 46,249 ditahun 2015, hal ini sejalan dengan jumlah masyarakat yang melakukan konversi agama dengan jumlah penduduk yang mayoritas muslim, kehadiran masyarakat yang beragam dalam keyakinan tentunya akan menghadirkan fenomena Religioulitas yaitu mengenai perpindahan Agama/konversi Agama.

Pindah agama / Konversi Agama bukan merupakan suatu kesalahan yang dilakukan seseorang, tetapi merupakan pilihan yang memerlukan banyak pertimbangan dalam hidup individu. Tetapi pada kehidupan nyata, individu bersinggungan dengan pihak-pihak lain yang bisa saja mempermasalahkan perpindahan tersebut. Adapun alasan peneliti memilih objek konversi Agama Kristen ke Agama Islam di Garut Kota, 
dengan berbagai macam keberagaman seperti keragaman sosial, budaya ataupun Agama. Agama menjadi salah satu hal yang sangat menarik untuk diangkat menjadi sebuah penelitian hal ini karena berdasar pada beberapa faktor yang telah dibahas sebelumnya, selain itu berpindah Agama bagi sebagian orang adalah hal yang tabu untuk dilakukan, konversi Agama sangat bertentangan dengan keyakinan/keimanan yang dipeluk oleh para pelaku konversi Agama. Pindah agama / Konversi Agama bukan merupakan suatu kesalahan yang dilakukan seseorang, tetapi merupakan pilihan yang memerlukan banyak pertimbangan dalam hidup individu. Tetapi pada kehidupan nyata, individu bersinggungan dengan pihak-pihak lain yang bisa saja mempermasalahkan perpindahan tersebut, pindah Agama tentunya akan menghasilkan beberapa motif, pengalaman maupun makna yang didapatkan oleh pelaku konversi Agama.

Beragam motif dari berbagai informan sebagai para pelaku konversi agama, Sucipto adalah salah satu informan yang memilih Agama Islam sebagai tindakan konversi agama. Sucipto yang dulunya sebagai pemeluk agama Kristen mengungkapan melakukan konversi agama sebagai upaya untuk memenuhi salah satu syarat dari pernikahan. Awalnya sucipto yang mengajak calon istrinya untuk memeluk agama Kristen namun calon istrinya menolak ajakan Sucipto. Sucipto juga mendeskripsikan tentang kecintaannya kepada calon istrinya sehingga mengikuti agama yang dianut oleh istrinya yaitu agama Islam. Lainnya halnya dengan Hassanudin sapaanya, beliau menceritakan tentang motif yang menjadikan agama Islam sebagai tindakan konversi agamanya. Keluarga adalah factor yang paling kuat untuk menjadikannya sadar akan kebenaran yang hakiki, sebelum Hassanudin kedua orang tuanya terlebih dahulu memeluk agama Islam diikuti olehadiknya, bahkah sampai beberapa tahun Hassanudin menjalani kehidupan beragama yang berbeda ditengah-tengah keluarganya, perasaannya campur aduk, antara gelisah, hilang tujuan bahkan tidak ada lagi rasa semangat hidup namun akhirnya Hassanudin secara rutin membaca buku-buku tentang islam. tanpa paksaan dan tanpa keraguan Hassanudin pun bersedia untuk bersyahadat didepan ustad beserta kedua orangtuanya.

Hal ini sependapat sebagaimana yang diutarakan Sholeh (1997: 65) Agama dibutuhkan manusia untuk kepentingan mewujudkan kebahagiannya, dan wujud kebahagiaan manusia dipengaruhi oleh dimensi empirik kehidupan dunia yang berlangsung melewati perjalanan sejarahnya. Konversi agama bagi para informan 
mempunyai makna yang sangat dalam. Konversi agama bagi Hassanudin adalah berubah dari kondisi yang kurang baik ke arah yang lebih baik, berpindah dari kehidupan yang kurang benar kepada yang benar, berpindah dari yang kurang tepat kepada yang dinilai lebih tepat. Konversi berarti berubah dari yang kurang baik kepada yang lebih baik. Perpindahan dari agama semula kepada agama Islam, bagi para pelaku konversi semisal Hassanudin karena keinginannya untuk berubah kepada kondisi kehidupan yang lebih baik. Konversi agama tidaklah cukup pada lahiriah saja (Islam KTP) tetapi juga harus berkonversi pada isinya sekaligus. Cerita lain datang dari Anisa "sapaannya" ia mengungkapkan bahwa makna konversi agama adalah merubahnya seluruh tata cara kehidupan, berubah keyakinan, jika dulu Anisa meyakini tuhan itu adalah Yesus dan Allah adalah Tuhan bapak maka setelah melakukan konversi agama semuanya itu berbeda, keyakinan pun semakin kuat bahwa Allah adalah tuhan satusatunya sedangkan yang dimaksud Yesus adalah Nabi Isa as.

Berangkat dari fenomena konversi agama yang dilakukan oleh pelaku, maka penulis menetapkan teori yang dijadikan pisau bedah untuk mengkaji fenomena komunikasi religius ini, yaitu teori Fenomenologi. Menurut Kuswarno (dalam Nurhadi, 2015: 36) definisi dari teori Fenomenologi adalah cara membangun pemahaman tentang realitas. Pemahaman tersebut dibangun dari sudut pandang para aktor sosial yang mengalami peristiwa dalam kehidupannya. Pemahaman yang dicapai dalam tataran personal merupakan konstruksi personal realitas atau konstruksi subjektivitas. Tujuan utama fenomenologi adalah mempelajari bagaimana fenomena dialami dalam kesadaran, pikiran, dan dalam tindakan, seperti bagaimana fenomena tersebut bernilai atau diterima secara estetis. Fenomenologi mencoba mencari pemahaman bagaimana manusia mengkontruksi makna dan konsep-konsep penting, dalam kerangka intersubjectivitas. Intersubjektivitas karena pemahaman kita mengenai dunia dibentuk oleh hubungan kita dengan orang lain. Walaupun makna yang kita ciptakan dapat ditelusuri dalam tindakan, karya, dan aktivitas yang kita lakukan, tetap saja ada peran orang lain di dalamnya (Kuswarno, 2009: 4)

Berdasarkan pemaparan yang telah dijelaskan, maka penulis tertarik untuk melakukan penelitian komunikasi religius yang berjudul: "Motif konversi Agama"(Studi Fenomenologi tentang Motif Konversi Agama Kristen ke Agama Islam di Garut Kota). 
Penelitian ini menggunakan pendekatan kualitatif. Pendekatan ini, menitikberatkan pada observasi partisipan dan suasana ilmiah (natural setting). Peneliti terjun langsung kelapangan, bertindak sebagai pengamat untuk membuat kategori prilaku, mengamati gejala, dan mencatatnya dalam buku observasi. Terkait dengan judul motif konversi agama (agama Kristen ke agama Islam), peneliti dapat mempelajari bentuk-bentuk motif, pengalaman dan makna dari para informan sebagai pelaku yang melakukan konversi agamadari sudut pandang orang yang mengalaminya langsung. Adapun informan yang dijadikan subjek pada kajian ini sebanyak 7 orang secara purfosif sampling.

Pemilihan informan didasarkan kepada informan yang mampu menggambarkan kembali fenomenanya yang telah dialaminya terutama dalam sifat alamiah motif dan maknanya, bersedia untuk terlibat dalam kegiatan penelitian, serta bersedia untuk diwawancara dan direkam aktivitasnya selama wawancara atau selama penelitian berlangsung. Teknik pengumpulan data yang digunakan adalah wawancara mendalam, observasi partisipan dan studi pustaka.

Adapun kriteria pemilihan informan menggunakan purposive sampling. Menurut Kriyantono (2006: 158) menyatakan bahwa: teknik ini mencakup orang-orang yang diseleksi atas dasar kriteria-kriteria tertentu yang dibuat periset berdasarkan tujuan riset. Sedangkan orang-orang dalam populasi yang tidak sesuai dengan kriteria tersebut tidak dijadikan sampel.

Adapun kriteria informan dalam penelitian ini adalah:

1. Merupakan warga Garut Kota;

2. Usia minimal 20 tahun;

3. Melakukan konversi Agama Minimal 2 tahun;

4. Memiliki keterbukaan dan ketersediaan menjadi Informan;

5. Bersedia memberikan gambaran dan proses konversi yang di alaminya.

\section{Pembahasan}

Pada bab ini peneliti membahas mengenai keseluruhan hasil temuan yang peneliti temukan termasuk di dalamnya tahap wawancara mendalam, observasi dan studi pustaka. Peneliti akan membahas hasil dari sudut pandang peneliti dan sudut pandang informan. Pembahsan dari sudut pandang peneliti didapatkan dengan 
menginterpertasikan hasil wawancara dengan hasil penelitian. Pembahasan dari hasil penelitian juga didukung dengan hasil wawancara terhadap tujuh informan yang melakukan konversi agama dari agama Kristen ke agama Islam di Garut Kota yang bersangkutan dengan penelitian ini. Pembahsan dari sudut pandang peneliti dengan menginterpertasikan hasil wawancara dan observasi dengan penelitian.

Pada penelitian ini peneliti melakukan wawancara dengan informan yaitu pelaku konversi agama Kristen ke agama Islam di Garut Kota yang peneliti pilih. Proses wawancara dengan informan sendiri dilakukan oleh peneliti dalam jangka waktu kurang lebih dua bulan lamanya, melalui wawancara langsung dan observasi yang dilakukan dengan mendatangi langsung lokasi tempat tinggal informan tersebut. Sebelum melakukan penelitian, peneliti terlebih dahulu membuat perjanjian dengan informan untuk melakukan wawancara dan kesepakatan mengenai hal-hal apa saja yang bias ditulis oleh peneliti dan tidak bisa ditulis oleh peneliti menyangkut hal yang menjadi rahasia bagi mereka. Karena jadwal dan waktu yang padat untuk melakukan aktivitas lainnya maka peneliti harus membuat jadwal dengan para informan, maka dari itu peneliti melakukan perjanjian terlebih dahulu untuk menyesuaikan jadwal dan aturan main dengan para narasumber, agar penelitian dapat berjalan dengan lancar.

Proses wawancara dilakukan di beberapa tempat yaitu kediaman tempat para informan, ditempat kerja, ataupun ditempat mereka biasa nongkrong. Adapula peneliti melakukan wawancara melalui media yaitu e-mail sebagai tambahan atau pertanyaan yang masih belum peneliti pecahkan mengenai penlitian yang dilakukan. Hal ini, dilakukan peneliti agar mendapatkan hasil yang lebih maksimal juga objektif.

\section{Motif Informan Melakukan Konversi Agama Kristen ke Agama Islam}

Hasil penelitian ini, akan menguraikan tentang aspek-aspek yang terkait dengan motif, pengalaman dan makna konversi agama kristen ke agama Islam. Berdasarkan hasil yang dilakukan, peneliti mendapatkan hasil yang beragam mengenai motif, pengalaman dan makna pelaku yang melakukan konversi agama dari Agama Islam ke Agama Kristen. Motif yang dihasilkan terbagi dalam dua kategori jenis motif yaitu motif "in order to", artinya bahwa sesuatu merupakan tujuan yang digambarkan sebagai maksud, rencana, harapan, minat, dan sebagainya yang berorientasi pada masa depan. Dengan kata lain, jenis motif ini lebih kepada alasan seseorang melakukan tindakan 
sebagai usahanya menciptakan situasi dan kondisi yang diharapkan dimasa yang akan datang atau harapan dimasa yang akan datang. Sedangkan motif 'karena'(because motives), artinya sesuatu merujuk pada pengalaman masa lalu individu, karena itu berorientasi pada masa lalu, yaitu dimana aktor atau seseorang merujuk pada beberapa faktor yang berkaitan dengan pengalaman masa lalu yang dilakukan oleh informan. Tindakan konversi agama dilakukan oleh para pelaku merupakan tindakan yang bertentangan dengan agama yang dianut bahkan konversi agama merupakan suatu hal yang tabu dimasyarakat umum. Motif yang mendasari informan melakukan konversi agama Kristen ke agama Islam dapat dilihat seperti dalam beberapa pernyataan dengan beberapa informan yaitu:

Bapak Chusmayadi (Informan 1) dalam wawancara santai di kantor tempat ia bekerja beliau memaparkan motif nya sebagai berikut:

Tindakan konversi Agama yang saya lakukan sudah membuat hidup saya lebih baik dari waktu ke waktu tujuan saya melakukan konversi agama adalah untuk mendapatkan kebahagian dunia dan kebahagiaan akhirat, sebelum melakukan konversi agama kehidupan saya terasa semrawut tidak jelas arah, hampa sering melakukan ibadah ke Gereja namun hati saya sering gundah dan tidak tenang. Saya sangat menginginkan kebahagian dan akhirnya saya pun merasakan kebahagian yang tiada tara setelah menjadi Muallaf mempelajari ajaran Agama Islam dan Allhamdulilah sampai saat ini pun saya mensyukuri ni'mat yang Allah berikan khususnya kepada saya berupa ni'mat iman dan ni'mat Isam (Hasil Wawancara dengan Bapak Chusmayadi).

Dari pemaparan informasi yang diutarakannya, motif tujuan dapat dilihat melalui keinginan dari Bapak Chusmayadi untuk melakukan konversi agama tidak lain adalah untuk mendapatkan kebahagiaan dunia dan kebahagiaan akhirat. Meskipun rajin beribadah di Gereja Chusmayadi tidak merasakan kebahagiaan, kedamaian, ketentraman maka hal demikianlah yang membuat Chusmayadi lebih terbuka pada keyakinan yang membuat dirinya mantap untuk menjadi seorang Muslim dan kebahagiaan didapatkan oleh Chusmayadi setelah menjadi Muslim. Bapak Nopi Susanto (Informan 2) dalam sebuah wawancara memaparkan motif tujuan yang menjadikannya memutuskan untuk menjadi seorang Muallaf dalam tindakan konversi Agama nya sebagai berikut :

Konversi agama atau perpindahan agama dari Kristen ke agama Islam yang saya lakukan merupakan suatu hal yang sangat tepat dimana saya memiliki tujuan yaitu untuk mendapatkan pencerahan hidup dan keseimbangan hidup. Dalam setiap hal yang saya lakukan (pekerjaan yang diperbolehkan agama) jika diawali dengan niat maka itu akan menjadi suatu amal baik ungkapnya. Sedangkan keseimbangan hidup nopi mengatakan bahwa agama Islam merupakan agama 
yang sangat sempurna yaitu hablumminalloh dan hablumminnas yang mendepinisakan bahwa kita sebagai manusia harus menyeimbangkan antara kebutuhan duniawi untuk ukhrowi urusan dunia tidak boleh diutamakan ketimbang urusan akhirat begitupun sebaliknya (Hasil Wawancara dengan Bapak Nopi).

Dalam pemaparan yang dijelaskan, konversi agama yang dilakukan oleh Nopi dapat dilihat dari tujuan Nopi (Informan 2) melakukan konversi agama yaitu untuk mendapatkan pencerahan hidup dan mencapai keseimbangan hidup. Konversi agama yang dilakukan oleh Nopi memang menjadi salah satu alasan untuk mendapatkan pencerahan hidup dalam kesehariannya Nopi ketika sebelum menjadi muslim hidupnya terasa hampa tidak jelas arah sehingga ada harapan besar yang diinginkan oleh Nopi setelah menjadi muslim hidupnya lebih terarah karena pada hakikatnya agama Islam adalah agama yang menuntun umatnya pada jalan yang benar. Selain itu, nopi juga mempunyai tujuan dalam tindakan konversi agama yang dilakukannya yaitu untuk mendapatkan keseimbangan hidup dimana Nopi menginginkan adanya keseimbangan dalam menjalani hidup sebagai muslim yang taat pada segala perintah Allah dan menjauhi larangan Alloh. Dalam menjalani kehidupan Nopi menginginkan adanya keseimbangan antara urusan dunia dan urusan Akhirat. Beberapa pernyataan yang telah dipaparkan, maka peneliti mengkategorisasi ada beberapa motif yang disajikan dalam bentuk model komunikasi pada bagan 1, yaitu: 


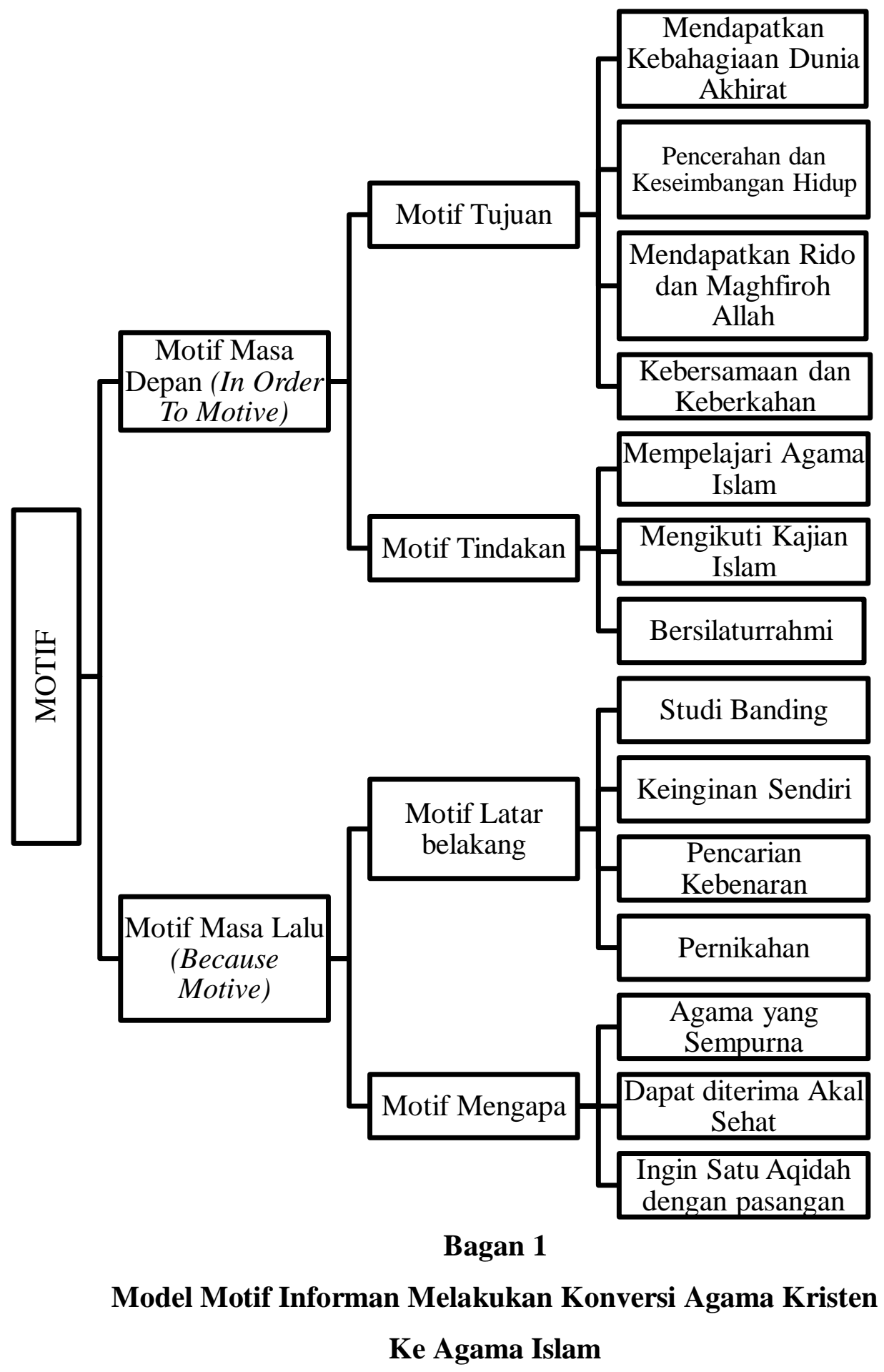

(Sumber: Model Kategorisasi pengamatan dan wawancara pada informan tahun 2017)

\section{Pengalaman Konversi Agama Kristen Ke Agama Islam}

Pengalaman itu dapat diartikan sebagi suatu peristiwa yang dialami dalam hidup seseorang atau diri kita sendiri. Sedangkan pengalaman religulitas pada hakikatnya 
berarti bahwa manusia mengakui hidupnya sendiri sebagai pemberian dari Allah. Sedangkan pengalaman komunikasi yang dianalisis adalah pengalaman tentang bagaimana setiap pelaku konversi agama Kristen ke agama Islam. Tentu setiap individu memiliki perspektif dan pengalaman yang dialaminya.Pengalaman yang mendasari informan melakukan konversi agama Kristen ke agama Islam dapat dapat terlihat melalui wawancara yang dilakukan peneliti dengan Bapak Chusmayadi (Informan 1) beliau memaparkan pengalamannya sebagai berikut:

Pertama kali masuk Islam itu ditentang keras oleh orangtua saya hal ini berdasarkan pada pandangan orangua/stereotip orangtua pada agama Islam itu buruk seperti halnya melihat orang-orang Islam yang mabuk-mabukan, berjudi. Jadi persangka orang tua kepada saya melakukan perpindahan agama adalah ingin bergaul dengan orang Islam, ingin bebas bergaul, hal itulah yang ditakuti orangtua saya. Bahkan ibu saya menganggap saya gila. Bahkan saya diusir dari rumah dan Allhamdulilah ada yang bersedia menampung saya yaitu KH.Karhi pengurus pondok pesantern Darul Arqom. Setelah masuk Islam saya bisa memilah dan memilih mana yang memberikan damfak positif dan mana yang harus saya jauhi. Tapi sekarang saya buktikan bahwa saya sungguh-sungguh dalam mencapai cita-cita dan tindakan saya berpindah keyakinan merupakan langkah yang sangat baik dalam meningkatkan kualitas kehidupan saya. Saya pernah menjadi Guru agama disekolah bahkan Allhamdulilah saya sekarang kan menjadi Pegawai Negeri Sipil (Hasil Wawancara dengan Bapak Chusmayadi).

Berdasarkan pemaparan tersebut, Chusmayadi (Informan 1) menyampaikan pengalamannya melakukan konversi agama dihiasi oleh berbagai keadaan seperti halnya ketika dirinya melakukan konversi agama, keluarganya menentang keputusan Chusmayadi melakukan konversi agama, pertama kali masuk Islam Chusmayadi ditentang keras oleh orangtuanya berdasarkan pada pandangan orangtua/stereotip orangtua pada agama Islam itu buruk seperti halnya melihat orang-orang Islam yang mabuk-mabukan, berjudi. Jadi persangka orang tua kepada Chusmayadi melakukan konversi agama adalah ingin bergaul dengan orang Islam, ingin bebas bergaul, hal itulah yang ditakuti orangtua Chusmayadi. Selain itu ada ada pedoman bagi orang Tionghoa dimanapun saya tinggal selama bumi dipijak dan langit dijujung maka saya harus mempunyai kekayaan, karena memang harta dan kekayaan adalah hal yang utama. Maka hal ini juga yang menjadi tentangan dari orangtua Chusmayadi. Bahkan Chusmayadi dikatatai oleh orangtuanya gila setelah menjadi orang Islam. tidak sampai disitu, Chusmayadi di usir oleh keluarganya namun Chusmayadi beruntung karena dapat diterima oleh KH. Karhi pengurus Pondok pesantren darul Arqom. Setelah 
melakukan konversi agama Chusmayadi mendapatkan banyak saudara baru karena pada dasarnya dengan sesama Muslim semua bersaudara ungkapnya.

Sedangkan menurut Nopi Susanto (Informan 2) mengungkapkan Pengalamanya konversi agama yang dialaminya:

Keluarga saya sendiri dapat dikatakan sebagai pemeluk agama Kristen yang taat karena setiap waktu beribadah kita semua kompak melaksanakan kegiatan beribadah tersebut secara bersama. Intensitas saya pergi ke gereja makin buruk keluarga sering menanyakan tentang sikap saya karena jarang pergi ke gereja namun saya jawab saja dengan santai. Seiring berjalannya waktu saya semakin yakin bahwa agama Islam adalah Agama yang benar ada rasa hidup menjadi tenang, lebih terarah dan ajarannya masuk akal. Pada tahun 2006 akhirnya saya memutuskan untuk menjadi seorang muslim dan membacakan dua kalimah Syahadat yang disaksikan oleh Ustadz dikampung halaman saya. Timbulnya juga rasa kebahagiaan yang ada pada diri saya bahagia lahir batin apalagi ketika dalam suatu pengajian saya mendengarkan ceramah ustadz bahwa barang siapa yang bersyukur maka Alloh akan memberikan ni'mat yang lebih besar. Saya menyatakan diri kepada orang tua saya dengan menkomunikasikan bahwa saya telah memeluk agama Islam, saya berbicara secara baik-baik kepada orangtua dalam persoalan perpindahan keyakinan. Orangtua sendiri legowo atas pilihan saya karena memang meyakini bahwa keputusan yang diambil telah dipikirkan matang namun tetap saja ada yang keras menolak bahkan tidak mau melihat saya atau mengenal saya lagi, ada yang mengahiri persahabatan adapula yang mengikhlaskan, namun yang saya rasakan setelah saya berpindah agama, banyak masyarakat yang lebih peduli, perhatian kepada saya sendiri (Hasil Wawancara dengan Bapak Nopi).

Bedasarkan pemaparan yang telah dijelaskan Nopi (Informan 2) mempunyai pengalaman karena melakukan konversi agama sebagai berikut Nopi lahir dan besar di keluarga yang menganut agama Kristen, keluarga Nopi bisa dikatakan sebagai pemeluk agama Kristen yang taat karena setiap waktu beribadah semuanya kompak melaksanakan kegiatan beribadah tersebut secara bersama. Nopi dengan sesama memang tidak dihalangi oleh keyakinan malahan Nopi lebih senang bergaul dengan orang muslim. Nopi merasakan hal yang sangat luar biasa tersirat dalam hatinya ingin belajar mengenai agama Islam sampai saat nya Ali pun mulai meragukan agama yang dianut oleh keluarga besar. Nopi terus belajar tentang agama Islam. Seiring berjalannya waktu Nopi semakin yakin bahwa agama Islam adalah Agama yang benar ada rasa hidup menjadi tenang, lebih terarah dan ajarannya masuk akal.

Ada banyak perubahan yang Nopi alami diantaranya hidup semakin yakin, semakin semangat dalam menjalani aktivitas. Timbulnya juga rasa kebahagiaan yang 
ada pada diri saya bahagia lahir batin. Nopi tidak menyesali atas keputusan yang saya ambil yaitu berpindah keyakinan sama sekali tidak menyesal. Momen haru terjadi saat lebaran idul fitri, setelah satu bulan lamanya berpuasa semua tercurah pada waktu tersebut dengan sesama saling minta maaf saling memaafkan hal tersebutlah yang belum dialami oleh Nopi sebelumnya. Hasil penelitian dari pengalaman pelaku konversi agama, maka peneliti menyajikan dalam bentuk model komunikasi pada bagan 2 , yaitu: 


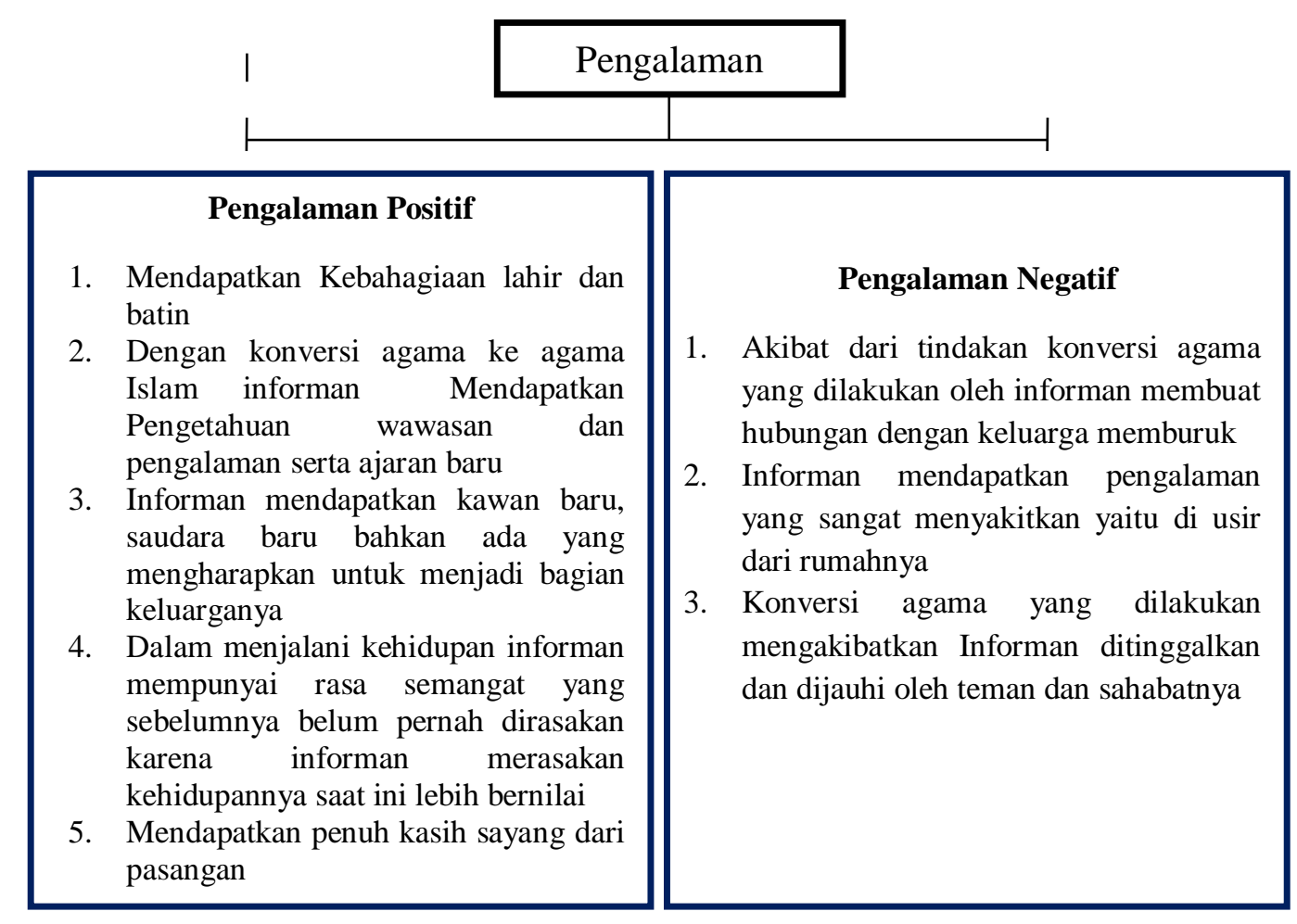

\section{Bagan 2}

\section{Model Pengalaman Konversi Agama Kristen Ke Agama Islam}

Sumber: Model kategorisasi pengamatan dan wawancara tahun 2017

\section{Makna Konversi Agama Kristen Ke Agama Islam}

Makna muncul dari pemikiran seseorang saat melihat sebuah fenomena. Tentu saja jika berbicara tentang makna akan berbeda hasilnya antar satu dengan yang lain. Sekalipun ada persamaan itu pun sedikit dan masih ada perbedaan satu dua kata yang dilontarkan oleh setiap orang. Berdasarkan hasil wawancara dengan informan tersebut, maka diperoleh hasil sebagai berikut :

Menurut Chusmayadi (Inporman 1) menungkapkan makna konversi Agama Kristen ke Agama Islam sebagai berikut

Pindah agama/konversi agama menurut saya adalah berpindahnya keyakinan pindah tata cara kehidupan. Makna Konversi agama bagi saya bagi kehidupan. Setelah saya masuk Islam mempelajari ajaran agama Islam masuk pesantren meneruskan pendidikan ya saya sangat senang sekali karena memang dalam pergaulan saya pribadi dapat diterima lebih baik dilingkungan yang mayoritas agama islam. Selain itu Allhamdulilah saya dipercayai oleh Alloh menjadi 
Ustadz maaf ya "Bukan Takabur" ketika orang Tionghoa jago ngaji jago ceramah lihai dalam menyampaikan ayat suci al-Qur'an maka Jemaah itu akan terkagum. Agama Islam adalah agama yang menyelamatkan setelah saya mempelajari agama Islam saya lebih memahami bahwa agama Islam adalah agama Yang baik dan benar (Hasil Wawancara dengan Bapak Chusmayadi).

\section{Berdasarkan pemaparan yang dijelaskan, Chusmayadi (Infroman 1)} memberikan jawaban mengenai konversi agama baginya dan makna agama Islam. Konversi agama menurut Chusmayadi adalah berpindahnya keyakinan yaitu berpindahnya keyakinan yang awalnya mengenal tuhan itu ada tiga yaitu tuhan bapak (Allah), tuhan ibu (Maria) dan tuhan anak (Isa) hal ini dijelaskan pula oleh Chusmayadi bahwasannya setelah masuk Islam meyakini bahwa Tuhan itu hanya Allah SWT sedangkan Maria itu adalah mahluk Allah SWT yang mempunyai anak isa atau lebih dikenal sebagai Nabi. Pindah tata cara kehidupan artinya disini sendiri bagaimana kita sebagai muslim melakukan aktivitas yang sebelumnya dialami oleh Chusmayadi ternyata bertentangan dengan agama Islam tentunya hal ini akan merubah segala bentuk aktivitas yang kita jalani. Makna konversi agama bagi Chusmayadi sendiri itu mempunyai makna yang sangat besar hal ini dapat dilihat dari pernyataan Chusmayadi tentang makna berdasarkan pengalamannya yaitu diberikannya segala kemudahan oleh Allah Swt dalam menjalani kehidupan. Chusmayadi menjadi Pegawai Negeri Sipil (PNS) di Kementerian Agama Kabupaten Garut. Makna agama Islam Bagi Chusmayadi adalah agama yang menyelamatkan setelah dirinya mempelajari agama Islam Chusmayadi lebih memahami bahwa agama Islam adalah agama yang menyelamatkannya dari kesesatan.

Sedangkan menurut Nopi Susanto (Informan 2) mengungkapkan makna konversi agama baginya adalah:

Konversi Agama bagi peralihan seseorang (saya sendiri) untuk memeluk agama yang terdahulu kepada agama yang diyakini kebeenarannya pada saat ini dengan maksud untuk memperoleh ketenangan batin, pencerahan hidup dan ketentraman hidup. Makna konversi agama bagi saya adalah mengubah cara hidup lama dengan cara hidup yang baru. Banyak sekali perbedaan baik cara bersosialisasi dengan masyarakat umum, maupun cara beribadahnya. Tindakan konversi Agama yang saya lakukan sangat penting bagi diri saya sendiri karena saya merasakan begitu sempurnanya ajaran agama Islam. Agama Islam menjadi pedoman hidup yang terbaik bagi setiap manusia karena dapat menghilangkan rasa was-was, bimbang, dan dapat diterima nalar/pikiran kita (Hasil Wawancara dengan Bapak Nopi). 
Berdasarkan pernyataan dari beberapa informan terkait dengan makna pelaku konversi agama Kristen ke Agama Islam, maka penulis menyajikan dalam bentuk model komunikasi pada bagan 3, yaitu:

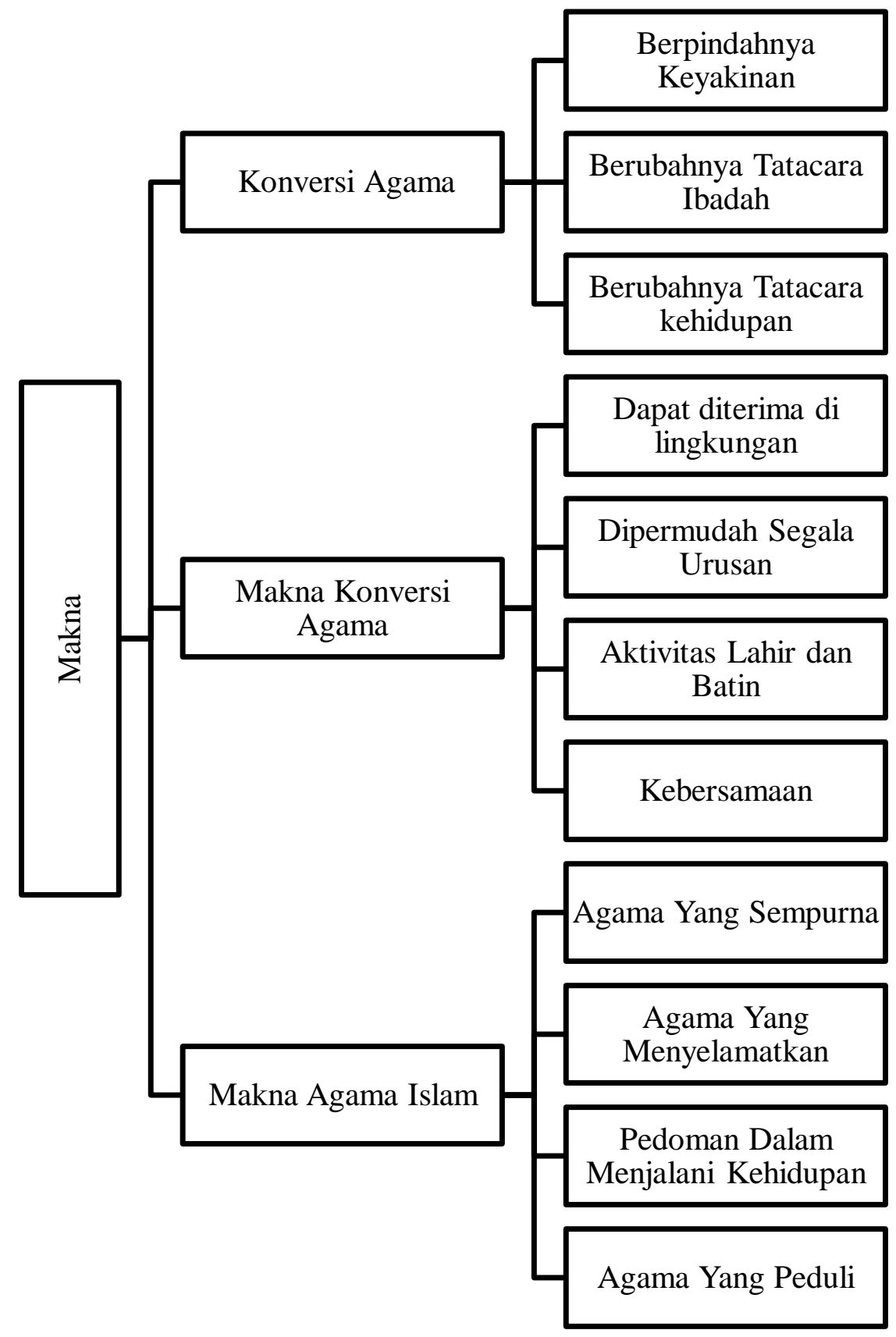

Bagan 3

Model Makna Konversi Agama Kristen Ke Agama Islam

Sumber: Model Kategorisasi pengamatan dan wawancara pada informan tahun 2017 
Pada bagian ini, peneliti akan menguraikan menjadi sebuah pembahasan dari motif, pengalaman dan makna pelaku konversi agama. Pembahasan juga merupakan interpertasi peneliti tentang hasil penelitian dengan analisis terkait teori dan konsep yang telah dikaji. Sebuah tindakan konversi agama tentunya mempunyai alasan-alasan yang melatarbelakanginya, alasan tersebut dapat disebut motif. Manusia secara sadar ataupun tidak, memiliki motif dibalik setiap kegiatan maupun dalam setiap interaksinya.

\section{Analisis Motif Konversi Agama Kristen Ke Agama Islam}

Motif merupakan dorongan, hasrat, keinginan, dan tenaga penggerak lainnya, berasal dari dalam dirinya, untuk lakukan sesuatu. Motif memberikan tujuan dan arah pada tingkah laku manusia. Jadi istilah motif erat kaitannya dengan gerak, yaitu gerakan yang dilakukan yang digerakan oleh manusia/ perbuatan/ tingkah laku (Gerungan, 2010: 151-152).Konversi agama menjadi fenomena yang cukup menarik untuk diperbincangkan. Konversi agama di Indonesia bukan hanya dilakukan oleh para artis ternama melainkan masyarakat umum pun banyak yang melakukan konversi agama, fenomena konversi agama muncul karena adanya perbauran budaya ataupun perbauran mayarakat yang berbeda agama, pada umumnya lingkungan sangat mempengaruhi seseorang untuk melakukan konversi agama. Dalam hal ini pelaku konversi agama tentunya memiliki motif tersendiri ketika memutuskan untuk melakukan konversi agama.

Motif tujuan sebagai alasan bagi pelaku konversi agama Kristen ke agama Islam untuk memenuhi kebutuhan spiritualnya. Banyak tujuan yang ingin dicapai oleh pelaku konversi agamanya seperti yang disampaikan oleh Chusmayadi dan Nopi Susanto, konversi agama yang dilakukannya untuk mendapatkan kebahagiaan duni dan akhirat selain itu adanya keinginan dari dalam diri untuk mendapatkan pencerahan dan keseimbangan hidup. munculnya tujuan melakukan konversi agama bagi pelaku konversi agama sebagai bentuk usahnya untuk mencapai cita-cita yang ingin dicapai. Meskipun pada kenyataannya konversi agama dianggap tabu oleh sebagian orang hal ini tidak berlaku bagi pelaku konversi agama karena hal ini berkaitan dengan keinginan pelaku konversi agama dimasa yang akan datang. Dengan tujuan tersebutlah maka motif tujuan termasuk kedalam jenis "in order to motive" karena muncul akibat adanya keinginan berupa tujuan yang ingin dicapai di masa yang akan datang. Motif tindakan 
adalah alasan dari para Informan mengutarakan kenginannya berupa tindakan yang ingin dilakukan dimasa yang akan datang. Tindakan disini dapat diartikan sebagai bentuk implementasi dari motif tujuan dimana pelaku konversi agama melakukan perbuatan sebagai bentuk keseriusannya dalam melakukan konversi agama. Bagi Muhammad Ali Santoso dan Anisa Nur Azizah motif tindakan yang dilakukannya adalah belajar mengenai ajaran agama Islam, mengikuti kajian agama Islam dan bersilaturahmi kepada alam ulama. Hal ini dilakukan oleh para informan sebagai bentuk keseriusannya melakukan konversi agama. Diharapkan dengan konversi agama para informan mendapatkan apa yang menjadi cita-cita dan juga kenginannya.

Motif karena (Because Motive) muncul karena pelaku konversi agama melihat kebelakang atau pengalaman dan pengetahuannya sebab memilih menjalani konversi agama. Motif latar belakang Chusmayadi tindakan konversi agama yang dilakukannya murni karena kenginannya sendiri, Chusmayadi melakukan konversi agama dilatar belakangi oleh tindakannya berupa membandingkan agama Islam dengan agama Kristen. Chusmayadi lebih memilih agama Islam karena ajarannya lebih jelas dan masuk akal. Lain halnya bagi Sucipto, dirinya melakukan konversi agama karena menginginkan adanya restu dan pemenuhan syarat bagi pernikahnanya.

Motif mengapa dan siapa sangat jelas di sampaikan oleh para informan. seperti bagi Pak Chusmayadi, Nopi Susanto, Muhammad Ali Susanto yang berpendapat bahwa agama Islam adalah agama yang sempurna, agama yang menuntun manusia pada jalan yang benar, ajaran agama islam dapat dipahami oleh akal (nalar) sedangkan menurut Sucipto dan Anisa Nur Azizah baginya melakukan konversi agama ke agama Islam karenan menginginkan satu awidah dengan pasangan yang akan dinikahinya. Kemudian seluruh para informan menyatakan bahwa agama Islam dikenal sejak kecil karena lingkungan para Informan adalah lingungan agama Islam.

\section{Analisis Pengalaman Konversi Agama Kristen Ke Agama Islam}

Pengalaman pada dasarnya melalui suatu proses dimana rangsangan dari luar seperti cahaya intik mata, bunyi untuk telinga, dan bau untuk hidung melalui alat-alat pancaindera diteruskan ke pusat-pusat tertentu didalam otak yang lalu menafisrkan sebuah pengamatan. Kita mengamati sesuatu karena ada inat perhatian yang mengadakan seleksi diantara semua rangsangan yang terdapat dilingkungan kita untuk 
diamati atau ditafsirkan, kevuali kita kerahkan minat perhatian kita dengan khsusus untuk menafsirkan semuanya. Minat perhatian itu ditentukan oleh struktur kebutuhan atau motif yang terdapat pada seseorang. Jadi, sebenarnya motif-motif kita, melalui minat dan perhatian kita mempunyai peranan besar dalam menentukan apa yang kita lihat, dengar, dan amati dilingkungan kita (Gerungan, 2010: 156-158). Pengalaman yang dialami oleh para informan sangat beragam. Bagi Chusmayadi, Muhammad Ali Santoso dan Sucipto konversi yang dilakukannya mengakibatkan keluarganya kecewa sehingga kedua informan tersebut di usir dari rumah, dikucilkan oleh orangtua dan keluarganya. Sedangkan bagi Nopi Susanto, Yaman dan Anisa Nur Azizah pengalaman konversi agama yang dilakukannya tidak begitu mendapat tentangan dari keluarga khususnya dari orangtua. Terlebih bagi Yaman hidup berdampingan meskipun berbeda agama sudah menjadi hal yang biasa. Selain itu pengalaman dari para informan tentang tindakan konversi agama yang dilakukannya mendapatkan perasaan tersendiri seperti halnya rasa bahagia, rasa tenang, rasa semangat, mendapatkan ilmu baru, mendapatkan saudara baru, dan pastinya mendapatkan ilmu baru.

Selain pengalaman bahagia para informan pun merasakan pengalaman yang membuat sedih. Konversi agama yang dilakukan oleh informan menimbulkan respon negatif dari sebagian orang terdekatnya. Seperti halnya Chusmayadi dirinya dikucilkan oleh keluarga bahkan diusir dari rumahnya sendiri. Sama halnya apa yang dialami oleh Muhammad Ali Santoso dan Sucipto. Konversi agama yang dilakukannya mendapatkan respon negatif dari orang-orang terdekatnya. Lain halnya apa yang dialami oleh Nopi susanto, meski mendapatkan respon positif dari orangtuanya Nopi ditinggalkan oleh teman dan sahabatnya karena tindakan konversi agama yang dilakukannya. Dalam melaksanakan ibadah puasa memiliki kesamaan dimana para informan pada awal masuk agama Islam memiliki kesulitan dalam menjalani ibadah puasa namun dengan berjalannya waktu infromanan pun lancar melaksanakan kewajibannya. Bagi para informan, agama Islam adalah agama yang sempurna hal ini didapatkan atas jawaban para informan yang menyatakan bahwa kesempurnaan agama yang mengatur seluruh aktivitas lahir maupun aktivitas batinnya. 


\section{Analisis Makna Konversi Agama Kristen Ke Agama Islam}

Makna dapat memperlihatkan bahwa setiap individu memiliki kemampuan berpikir sesuai dengan kemampuan serta kapasitas kognitif atau muatan informasi yang dimilikinya. Oleh karena itu, makna tidak akan sama atas setiap individu walaupun objek yang dihadapinya adalah sama. Pemaknaan terjadi karena cara dan proses berpikir adalah unik pada setiap individu yang akan menghasilkan keragaman dalam kontruksi makna (Bungin, 2006:2). Analisis penelitian ini sesuai dengan definisi makna menurut Juliastuti secara garus besar menurut hasil wawancara yang dilakukan peneliti, informan memiliki makna tersendiri mengenai konversi agama. Bagi para informan konversi agama adalah berpindahnya keyakinan yang diikuti oleh berubahnya seluruh tatanan kehidupan dan cara beribadah. Makna konversi agama bagi Chusmayadi dirinya dapat diterima di lingkungan masyarakat yang mayoritas agama Islam dan dipermudah segala urusannya, sedangkan bagi Nopi Susanto makna konversi agama baginya adalah mengubah cara hidup lama dengan cara hidup baru dimana dirinya merasakan kehidupan yang lebih bermakna daripada kehidupan sebelumnya. Bagi Muhammad Ali Santoso makna konversi agama yaitu mendapatkan penunjuk yang jelas dimana dirinya merasakan telah berada di jalan yang benar. Lain halnya dengan Sucipto konversi agama yang dilakukannya mempunyai makna adanya perubahan aktivitas lahir yaitu dengan beribadah kepada Allah SWT dan aktivitas lahir berupa berinteraksi dengan sesame muslim. Yaman mempunyai makna tersendiri yaitu adanya kebahagiaan yang dirasakan karena mendapatkan kebersamaan yang lebih bahagia bersama keluarganya.

\section{Simpulan}

Berdasarkan hasil penelitian, dapat ditarik suatu kesimpulan atas penelitian "Motif Konversi Agama Kristen Ke Agama Islam Di Garut Kota" sebagai berikut:

1. Motif konversi agama Krsisten ke agama Islam yang dilakukan oleh pelaku konversi agama bertujuan untuk mendapatkan pencerahan dan keseimbangan hidup. Selain itu pelaku konversi agama mempunyai tujuan untuk mendapatkan ampunan (Mafghfiroh) dari Alloh, pelaku juga mengharapkan adanya rasa kebersamaan bersama keluarga sehingga timbulnya rasa kebahagiaan bagi pelaku konversi agama baik itu kebahagiaan di dunia maupun kebahagiaan di akhirat kelak. 
2. Pelaku konversi agama mendapatkan pengalaman yang positif maupun pengalaman negatif. Pelaku konversi agama mempunyai pengalaman positif diantaranya mendapatkan kebahagiaan lahir dan batin, mendapatkan pengetahuan, wawasan dan pengalaman serta ajaran baru, pelaku juga mendapatkan kawan baru, saudara baru bahkan ada yang mengharapkan untuk menjadi bagian keluarganya. Dalam menjalani kehidupan pelaku konversi agama mempunyai rasa semangat yang sebelumnya belum pernah dirasakan karena merasakan kehidupannya saat ini lebih bernilai. Sedangkan pengalaman negatif pelaku mempunyai pengalaman yang menyakitkan, konversi yang dilakukan mengakibatkan keluarganya kecewa sehingga pelaku konversi agama di dikucilkan oleh orangtua dan keluarganya sampai diusir dari rumahnya sendiri, respon negative juga muncul dari orang-orang terdekatnya termasuk ditinggalkan oleh teman dan sahabatnya.

3. Makna Konversi agama bagi pelaku konversi agama Kristen ke agama Islam bukan hanya mengganti status keagamaan yang dianut, lebih dari itu konversi agama mempunyai makna yang dalam bagi pelaku konversi agama, diantaranya dapat dipermudahkannya segala urusan baik itu urusan dunia maupun urusan akhiratnya, mendapatkan kebersamaan bersama keluarga dan dapat diterima dilingkungan.

\section{Daftar Pustaka}

Bungin, Burhan. 2001. Metodologi Penelitian Kualitatif. Jakarta: Rajawali Pers.

Daradjat, Zakiyah. 2010 Ilmu Jiwa Agama. Jakarta: CV. Bulan Bintang.

Gerungan. 2010 Psikologi Sosial. Bandung: PT. Refika Aditama.

Kuswarno, Engkus. 2009. Metode Penelitian Komunikasi Fenomenologi. Bandung: Widya Padjadjaran.

Kriyantono, Rachmat. 2006. Teknis Praktis Riset Komunikasi. Jakarta: Kencana.

Nurhadi, Zikri Fachrul Nurhadi. 2015. Teori-Teori Komunikasi (Teori Komunikasi Dalam Perspektif Kualitatif). Bogor: Ghalia Indonesia.

Rakhmat, Jalaludin. 2016. Psikologi Agama. Depok: Raja Grafindo Persada.

Sholeh. 1997. Agama dan Pembangunan. Bandung: Pemerintah Propinsi DT.I Jawa Barat. 
https://www.satumedia.co/sejak-lima-tahun-terakhir-10-ribu-orang-jadi-mualaf-diindonesia-18402.

M.hukumonline.com/klinik/detai/cl6556/ham-dan-kebebasan-beragama-di-indonesia.

http://odhosuka.blogspot.co.id/2013/02/jenis-jenis-teori-motivasi.html.

http://www.referensimakalah.com/2013/05/teori-psikoanalisis-erickson.html?m=0.

http://klinis.wordpress.com/2007/12/27/konversi-agama-1/. 